\title{
World law'
}

\author{
Harold J. Berman \& Robert W. Woodruff \\ James Barr Ames 2 \\ School of Law \\ Emory University \\ School of Law \\ Atlanta \\ Harvard University \\ Georgia \\ USA \\ E-mail: hberman@law emory.edu
}

\begin{abstract}
World law

In the third millennium of the Christian era, which is characterised by the emergence of a world economy and eventually a world society, the concept of world law is needed to embrace not only the traditional disciplines of public international law, and comparative law, but also the common underlying legal principles applicable in world trade, world finance, transnational transfer of technology and other fields of world economic law, as well as in such emerging fields as the protection of the world's environment and the protection of universal human rights. World law combines inter-state law with the common law of humanity and the customary law of various world communities.
\end{abstract}

\section{The term "world law"}

In the twentieth century, for the first time in the history of the human race, most of the peoples of the world have been brought into more or less continual relations with each other. We speak without hesitation of a world economy, a world technology, world-wide communications, world organizations, world science, world literature, world scholarship, world travel, world sports. We speak

I This article, originally published in the Fordham International Law Journal, is presented here with the permission of the aforementioned joumal, with some changes, in tribute to Johan van der Vyver, whose important work, both scholarly and practical, in the area of universal human rights has made him an outstanding pioneer in the development of world law.

2 James Bar Ames is Emiritus Professor of Harvard University. 
Worid low

almost as confidently of an emerging world society, despite the forces of ethnic and territorial disintegration that threaten it. May we not speak also of world law?

The term "world law" will, I believe, become more and more widely used as humanity moves into a new century and a new millennium. It will embrace, but not replace, both the term "international law", introduced by Jeremy Bentham in 1789, and the term "transnational law", introduced by Philip Jessup in 1956. Eventual acceptance of the term world law will reflect as deep a conceptual change as that which occurred when the term "international law" replaced the older term "law of nations" (ius gentium).

In inventing the term "international law", Bentham contended that "law of nations" was objectionable because it combined three mutually contradictory elements:

- Natural law, defined as a system of rules derived from natural reason and common to all civilized peoples, which Bentham said was not law at all (Janis, 1984:405-407).

- Rules of mercantile and maritime law conceming private transactions that cross national boundaries, which Bentham said are governed by the applicable municipal law of one or another sovereign state.

- "The mutual transactions between sovereigns as such", which alone, in Bentham's view, could be called both "inter-national" (he spelled it with a hyphen) and law. ${ }^{3}$ As late as 1831, Bentham's neologism was called "a frightfully barbarous title" and a "vile pollution" (Hogg, 1988:115); yet Janis (1984:415) points out that it had already been widely adopted, ${ }^{4}$ and in time the positivist theory of international law which it reflected also came largely to prevail (Boyle, 1985:18).

In the latter half of the twentieth century, the "frightfully barbarous title" has been stretched to cover matters that hardly fit within Bentham's nationalist concept.

3 Bentham states: "The word inter-national, it must be acknowledged, is a new one". He adds, however, that D'Aguesseau (1668-1751) had previously stated that "what is commonly called droit des gens ought rather to be termed droit entre les gens". Id. at 293-294; see Janis, supra note 1, on 408-409. Janis (1984) also quotes D'Aguesseau's statement that jus gentium would be rendered more appropriately as jus inter gentes. Id. on $409, \mathrm{n} 27$

4 Even in his lifetime, Bentham saw the success of his new term. Not only in English but in other languages (e.g., droit imternational, internationales Recht, derecho internacional, internationaal recht), Bentham's concept caught hold. The older notion, the "law of nations", where it is still used, is commonly thought to be fungible with "international law". Janis (1984), supra note 1 , on 415 . 
Harold J. Berman, Robert W. Woodruff \& James Barr Ames

Especially after World War II, scholars began to look for new names to designate areas of law that transcend "mutual transactions between sovereigns as such". One such name was "United Nations law" or, more broadly, "the law of world organizations". Another was "the law of human rights". The most ambitious effort to find a name that would correspond to the realities of a new world order, however, was Jessup's proposal to replace the term "international law" by the term "transnational law". "The term 'international" is misleading", Jessup (1956:1) wrote, "since it suggests that one is concerned only with the relations of one nation (or state) to other nations (or states)". A term is needed, he said, to identify "the law applicable to the complex interrelated world community which may be described as beginning with the individual and reaching up to the socalled family of nations or society of states" (Jessup, 1956:1). [T] he word 'international' is inadequate to describe the problem ... the term "international law" will not do (Jessup, 1956:1).

[I] shall use, instead of 'international law,' the term 'transnational law' to include all law which regulates actions or events that transcend national frontiers. Both public and private international law are included, as are other rules which do not wholly fit into such standard categories" (Jessup, 1956:2).

The breadth of Jessup's definition is counteracted to a certain extent by the word "transnational", which takes the national state as a basic point of reference. When Jessup himself gave examples of matters that would be covered by "transnational" law, they were usually problems that ultimately involved "mutual transactions between sovereigns as such". Indeed, the word "transnational" refers back to the era of sovereign national states and indicates that it is to be transcended. It does not, however, give a new name to the new era that all humanity has entered. The right name for the new era, I submit, is "emerging world society", and the right name for the law by which it is govemed is "world law". 5

5 An important and widely used course-book entitled Transnational Legal Problems (Steiner et al., 1994:iii-iv) identifies as transnational "the ways in which a nation reacts to such problems as trade and monetary flows, how it controls immigration or regulates foreign conduct threatening its interests, and, in general, the ways in which its domestic policies necessarily affect other countries and their nationals".

S|uch expression of an international legal system can be viewed as having a transnational character. Together with public international law and with regulation by international organizations, such phases of international law form a ... complex to which this book refers as ... 'transnational law'.

Although this definition comes fairly close to what I call world law, nevertheless, "transnational" topics are usually treated by the authors in the context of their significance for inter-state relations 


\section{World law ... the law of the world economy}

World law is, in part, the law of the world economy. The world economy is not only a "transnational" economy; that is, it does not consist only of "foreign" trade, "foreign" investment, "foreign" exchange transactions, and other types of activity carried on across national boundaries. It consists also of certain types of activities carried on within a given national state by citizens of that state. Certain types of trade, investment, and financial transactions carried on, for example, between US business firms in New York and California may constitute an integral part of world trade, world investment, and world finance. We live not only in an "international" economy but also in a "world" of interdependent domestic economies. Moreover, the law that governs economic transactions between business firms in New York and California may be New York law or Califomia law or US federal law, but it may also be world law. If, for example, goods are shipped from California to New York by vessel via the Panama Canal, the ocean bill of lading will normally have the same legal character as an ocean bill of lading used in an export-import transaction between enterprises in any two countries in the world: it will constitute (a) the carrier's receipt for the goods, (b) evidence of the contract of carriage, and (c) a document of title. If payment for the goods (whether shipped by vessel, by rail, or by air) is by letter of credit, such credit will normally be subject to the same rules as those that govern letter-ofcredit transactions throughout the world. The exporters and importers of the world, the shipowners of the world, the bankers of the world, the marine insurance underwriters of the world, and others associated with them, including their lawyers, form a world community that, over the centuries, has made, and continues to make, the law by which their various types of transactions are governed (Berman, 1988:235; Berman \& Dasser, 1990:21-36). And many parts of that law may be applicable to domestic commercial transactions as well. Formally, the law applicable to a commercial transaction may be municipal law, but the municipal court will enforce the contract terms, and in certain types of transactions those terms are the customary terms used in world trade and, in that sense, constitute world law.

\section{Patterns and norms of behaviour}

The law of world trade is, of course, regulated in part by international conventions as well as by the laws of national states. So far as its strictly commercial aspects are concerned, however, its primary source is in the patterns and norms of behaviour of those who engage in it. Blackstone and his predecessors properly called it ius gentium, having in mind the older meaning of that term, "the law of peoples", applicable everywhere. It may also be called "transnational law", but that name does not suggest its universality, that is, its applicability to economic actors in carrying out certain types of domestic as well as foreign activities. 
The law of transfer of goods is, of course, only one part of world economic law. The law governing transfer of currencies and related financial transactions is another. The law governing direct foreign investment is a third. International law and national law play a greater role in the regulation of foreign exchange transactions and direct foreign investment than in the regulation of world trade transactions. Yet a customary world law based on the contract practices of economic actors plays an important role even with respect to money and investment. In addition, parallel developments in the national legislation of different countries as well as the adoption of international agreements have made substantial contributions to world law in those areas, as they have also in the area of transfer of goods. When one speaks of world law, therefore, one must include within it not only world customary law, in the sense indicated above, but also international law in Bentham's sense and transnational law in Jessup's sense.

\section{Other types of world communities}

In addition to the world communities of persons engaged in world trade, finance, investment, and other economic activities, there are many other types of world communities, including those represented by some thirty-five thousand voluntary not-for-profit non-governmental world organizations registered with the United Nations with members from many different countries. These include organizations engaged in the world-wide advancement of human rights, of medicine and health, of natural and social sciences, of engineering, travel, civil and political rights, charity and relief, environmental protection, world peace, international law, sports and leisure, and a large number of other activities (Boli \& Thomas, 1995). The interests that these associations represent constitute a vast infrastructure of world intercourse, involving patterns and norms of behaviour that give rise to universally recognized rights and duties. It is not mere coincidence that the rules of air traffic control, to take one example, are identical at every major airport in the world.

That humankind, in the aftermath of two world wars, has reached a turning point in its history, that the world has entered a new era of global interdependence, that all inhabitants of Planet Earth share a common destiny, is a historical fact, a political fact, an economic fact, a sociological fact, that has finally penetrated the consciousness of most of the earth's inhabitants. It has had a harder time penetrating legal scholarship or the curriculum of American law schools, which remain, for most students, provincial in the extreme. Even those students who take one or two elective courses in intemational law or comparative law or law of international trade and investment are not usually exposed to the interactions among these fields or to the interactions of all three with the customary law of communities that transcend national boundaries. 
Practising lawyers, on the other hand, are increasingly involved in world law. In the pregnant words of Benno Schmidt, former dean of Columbia Law School and later president of Yale University, "the world has replaced the nation as the context within which the professions operate". The law schools need the help of the practising profession in developing a curriculum in world law. At the same time, the practising lawyers whose clients are engaged in cross-border transactions need the help of scholars who are able to give a broader comparative and historical perspective, and a synthesis, to the myriad of practical problems with which the practitioners must deal.

The Benthamite concept that only sovereign states make law, and that consequently international law is made only by agreements between or among sovereign states, eliminated from the traditional sources of the law of nations both the common features of the various legal systems of the civilized world, previously characterized as natural law, and mercantile and maritime law, which were examples of the customary law of transnational communities. Let us leave the definition of international law as it is, but let us find a new name that will once again combine inter-state law with the common law of humanity, on the one hand, and the customary law of various world communities, on the other. We speak of a world economy, not only an international economy or even a transnational economy; its constituents are not only states but also, and primarily, economic enterprises. Similarly we will come, I believe, in the very near future, to speak of world law.

\section{Bibliography}

BERMAN, H.J. 1988. The Law of International Commercial Transactions (Lex Mercatoria) Emory Journal of International Dispute Resolution, 2:235.

BERMAN, H.J \& DASSER, F.J. 1990. The New Law Merchant and the Old: Sources Content and Legitimacy. (In Carbonneau, T.E., ed Lex Mercatoria and Arbitration. A Discussion of the New Law Merchant. Boston, Mass. : Kluwer Law International. p. 2136.)

BOLI, G. \& THOMAS, G.M. 1995. Organizing the World Polity: INGOs Since 1875. (Paper presented at annual meeting of International Studies Association, Chicago, February 1995.)

BOYLE, F A. 1985. World Politics and International Law. Durham, N.C. : Duke University Press.

BURNS,J.H. \& HART, H.L.A., eds. 1970. Jeremy Bentham. An Introduction to the Principles of Morals and Legislation. London : Clarendon.

HOGG, T.J. 1988. An Introductory Lecture on the Study of the Civil Law. (In Hoeflich, M.H., ed. The Gladsome Light of Jurisprudence: Learning the Law in England and the United States in the Eighteenth and Nineteenth Centuries. New York: Greenwood Press. p. 115.)

JANIS, M.W. 1984. Jeremy Bentham and the Fashioning of International Law American Journal of International Law, 78:405-407.

JESSUP, P C. 1956. Transnational Law. New Haven: Yale University Press

STEINER, H.J., VAGTS, D.F \& KOH, H H. 4th ed. 1994 Transnational Legal Problems Materials and Texts. Mineola, N Y. : Foundation Press 